\title{
De evolutie in de waardering van studenten en docenten van probleemoplossingsgerichte klinische colleges
}

\author{
J. Beullens, E. Struyf, H. Jaspaert, B. van Damme, C. Aubry, P.J. Janssen
}

\section{Samenvatting}

Inleiding: In de medische opleiding aan de Katholieke Universiteit (KU) Leuven zijn in 20002001 probleemoplossingsgerichte klinische colleges geïntroduceerd. Er waren twee reeksen van ongeveer zeventig colleges in acht weken. De colleges worden voorbereid in groepjes van vijf studenten aan de hand van één of meer vignetten (casus) met vragen. Studenten zoeken individueel informatie op. De vignetten worden tijdens het college besproken onder leiding van een docent. In 2000-2001 evalueerden studenten en docenten deze colleges.

Methode: De vragenlijst voor studenten (20 items) en docenten (15 items) kon na elk college ingevuld worden. De meeste items waren stellingen met antwoorden op een zespuntenschaal. Er werden 14.448 studentenvragenlijsten verwerkt. De aanwezigheid was in reeks 1 hoger dan in reeks 2 en daalde significant in de loop van beide reeksen. Na les 1 werden meer formulieren ingevuld dan na les 2 en het aantal verschilde per discipline. Er werd meer tijd besteed aan voorbereiding in reeks 1 dan in reeks 2, en meer aan groepswerk dan aan individueel werk. De bestede tijd verminderde significant tijdens elke reeks en verschilde tussen disciplines. De appreciatie was over het algemeen hoog. De 107 verwerkte docentenvragenlijsten gaven een hoge appreciatie te zien en geen significante verschillen tussen lessen of reeksen.

Discussie en conclusie: Studenten en docenten oordeelden gunstig over de colleges. De verschillen die optraden in aanwezigheid, voorbereiding en appreciatie in de loop van deze probleemgestuurde onderwijscomponent zouden bij een eenmalige evaluatie niet gevonden zijn. De bevindingen resulteerden in bijsturing van de formule via een introductiedag voor studenten en geen vaste weekdag meer per discipline. (Beullens J, Struyf E, Jaspaert $H$, Damme B van, Aubry C, Janssen PJ. De evolutie in de waardering van studenten en docenten van probleemoplossingsgerichte klinische colleges. Tijdschrift voor Medisch Onderwijs 2004;23(2):80-90.)

\section{Inleiding}

In het academisch jaar 2000-2001 werd in het laatste jaar van de (traditionele) medische opleiding aan de Katholieke Universiteit (KU) Leuven het probleemoplossingsgericht klinisch college (PoKC) geïntroduceerd als nieuwe onderwijsmethode. Als voorbereiding op het PoKC voeren studenten in kleine groepjes opdrachten uit aan de hand van een schriftelijke ziektegeschiedenis, waarbij ze individueel informatie dienen op te zoeken. Tijdens het plenaire PoKC worden de resultaten van de groepsopdrachten besproken onder begeleiding van één of twee docenten. Er wordt daarbij evenveel aandacht besteed aan de klinische redeneringen die naar verschillende oplossingsmogelijkheden leiden als aan de juiste oplossing. De reeks PoKC's wordt beëindigd met een schriftelijk examen met extended-matchingvragen die gebaseerd zijn op een ziektegeschiedenis.

Om deze methode te evalueren konden studenten en docenten na afloop van elk PoKC een vragenlijst invullen. Deze evalu- 
atie bood de studenten de mogelijkheid hun standpunt weer te geven en het begeleidend team de kans het proces desgewenst bij te sturen en de docenten na afloop van een reeks PoKC's feedback te geven. Op wat langere termijn wordt de informatie gebruikt om het PoKC als onderwijsmethode bij te schaven en de didactische kwaliteiten van de docenten door middel van docententraining te verhogen.

Over de evaluatie van probleemgestuurde onderwijscomponenten in een traditioneel curriculum is in de literatuur wel vaker gerapporteerd. Deze rapporten beperken zich vaak tot beoordelingen door studenten. ${ }^{1-5}$ Voorzover onderwijs beoordeeld werd door docenten, gebeurde dat meestal informeel. Evaluatie door studenten was doorgaans schriftelijk. ${ }^{6-7}$ Zelden werd in beide groepen een vragenlijst afgenomen. ${ }^{8-9}$ Het probleemgestuurd onderwijs duurde zelden langer dan een maand. ${ }^{2} 69$ Voorzover wij weten, is niet eerder onderzocht hoe het oordeel van studenten evolueert in de loop van een probleemgestuurde onderwijscomponent. In onderhavig onderzoek werd elk PoKC door zowel docenten als studenten beoordeeld aan de hand van een vragenlijst. Hierdoor was het mogelijk de evolutie van de appreciatie van de studenten en de docenten in kaart te brengen.

Aangezien de gegevens gebruikt worden voor feedback aan de docenten en bijsturing van de PoKC's, was de evaluatie onderzoeksmatig veeleer explorerend van aard dan hypothesetoetsend. Toch kunnen de bevindingen gebruikt worden om een antwoord te formuleren op de volgende onderzoeksvragen:

1. Hoe evolueerde de aanwezigheid van de studenten in de loop van de reeksen?

2. Hoe evolueerde de individuele en groepsvoorbereidingstijd in de loop van de reeksen?
3. Hoe evolueerde de globale appreciatie van de studenten van het PoKC en de appreciatie van het voor te bereiden probleem, de werkwijze van de docent en het verloop van het college?

4. Welke onderling onafhankelijke deelverzamelingen kunnen door middel van een factoranalyse in de vragenlijst van de studenten onderscheiden worden?

5. Wat vonden de docenten van hun colleges?

6. Veranderde hun oordeel van les 1 naar les 2 of van reeks 1 naar reeks 2 ?

\section{Methode}

\section{Organisatie van de PoKC's}

De PoKC's werden verzorgd door 63 docenten en bijgewoond door 358 studenten. Om de interactiviteit tussen de studenten onderling en tussen studenten en docent te bevorderen werden de colleges opgedeeld in twee reeksen en werden de studenten binnen elke reeks verdeeld in twee subgroepen die vlak na elkaar dezelfde les kregen. Zowel de indeling in reeksen als die in lessen gebeurde in vaste groepen van studenten.

De PoKC's werden gedurende acht weken gegeven in twee parallelle reeksen van ongeveer zeventig colleges. Dezelfde docent(en) gaven hetzelfde college aan de hand van dezelfde ziektegeschiedenis in de regel tweemaal op dezelfde dag (les 1 en les 2). De inhoud van de les kon alleen verschillen als de discussie een andere loop nam. Per docent worden dus twee colleges over hetzelfde onderwerp door twee verschillende groepen studenten beoordeeld.

Ten tijde van het onderzoek verzorgde elke discipline colleges op een vaste dag in de week: op maandag gynaecologie/verloskunde, op dinsdag inwendige geneeskunde, op woensdag heelkunde, op don- 
derdag pediatrie en op vrijdag de overige disciplines (huisartsgeneeskunde, dermatologie, fysische geneeskunde, KNO, neurologie, oftalmologie, psychiatrie), die als 'groep 5' werden aangeduid.

Elke reeks PoKC's eindigde met een examen.

\section{De vragenlijsten}

De vragenlijst voor de studenten bestond uit twintig items, waarvan de meeste als beweringen geformuleerd waren (tabel 1). Drie vragen betroffen de voorbereiding (zowel individueel als in de groep), drie vragen het probleem (zowel de relevantie van de ziektegeschiedenis als het uitdagend karakter van de opdrachten), zeven vragen de werkwijze van de docent (maakt gebruik van de resultaten van de voorbereiding en activeert studenten) en zes vragen betroffen de gang van zaken tijdens het college. In het laatste item werd een globaal oordeel gevraagd in de vorm van een respons op de bewering: "Ik vond dit een goed klinisch college". De studenten werd gevraagd op een zespuntenschaal $(1=$ helemaal niet akkoord tot $6=$ helemaal akkoord) aan te geven in hoeverre ze het eens waren met de stellingen.

De vragenlijst voor de docenten bestond uit vijftien items, overwegend beweringen (tabel 2). Twee vragen betroffen de voorbereiding, twee het vignet en elf het feitelijk verloop van het college. Net als bij de vragenlijst voor studenten dienden de beweringen op een zespuntenschaal beoordeeld te worden. Bij sommige vragen werd de docent uitgenodigd het antwoord te verduidelijken met commentaar.

\section{Subjecten}

De studenten konden na afloop van elk PoKC een vragenlijst invullen en die deponeren in een daarvoor voorziene doos. De vragenlijsten werden anoniem ingevuld. Elke docent die een PoKC ver- zorgde, beschikte over een vragenlijst en een envelop om het ingevulde formulier aan de Dienst Onderwijs te sturen.

\section{Statistische analyse}

Verschillen tussen groepen werden getoetst met behulp van de chikwadraattoets of variantie-analyse (ANOVA). Voor elk item afzonderlijk werd met behulp van ANOVA nagegaan of er significante verschillen waren tussen de reeksen, weeknummers (als indicator van de evolutie van het oordeel in de loop van de reeks), weekdagen (als indicator van de disciplinegroep) en lesnummers. Als er verschillen gevonden werden, werd met behulp van een t-toets nagegaan tussen welke deelgroepen de verschillen zich precies situeerden. Op de gegevens verkregen met de studentenvragenlijst werd een hoofdfactoren-analyse uitgevoerd, gevolgd door een varimaxrotatie. Het 5\%-significantieniveau werd gehanteerd.

\section{Resultaten}

Er werden 14.448 vragenlijsten verwerkt: 7831 uit reeks 1 (betreffende 63 docenten) en 6617 uit reeks 2 (betreffende 60 docenten). Aan de eerste reeks namen 181 studenten deel en aan de tweede 177.

\section{Het oordeel van de studenten}

\section{Evolutie van de aanwezigheid}

De resultaten op dit onderdeel worden weergegeven in figuur 1. Het aantal ingevulde formulieren per college werd beschouwd als een indicatie van het aantal aanwezige studenten. De aanwezigheid was significant hoger in de eerste reeks dan in de tweede ( $\mathrm{t}$-toets; $\mathrm{p}=.001$ ). In beide reeksen daalde het aantal ingevulde formulieren significant in de loop van de acht weken (regressieanalyses; p's < 0.001). Er was een significant verschil in het aantal ingeleverde formulieren tussen week- 
dagen (en dus per discipline) (chikwadraattoets; $\mathrm{p}<.001)$. Het aantal was significant lager na de colleges gynaecologie dan na de colleges heelkunde of pediatrie (t-toetsen; p's < .05). Na les 1 werden gemiddeld 109 formulieren $(S D=22.9)$ ingevuld en na les $2101(\mathrm{SD}=24.0)$ (telkens door dezelfde subgroepen uit beide reeksen samen). Er waren significant meer studenten aanwezig tijdens les 1 dan tijdens les 2 (t-toets; $\mathrm{p}<.001$ ). Per les werden in beide subgroepen samen ongeveer 180 studenten verwacht. Indien alle aanwezige studenten een formulier hebben ingevuld, heeft $55-60 \%$ de colleges gevolgd, wat een behoorlijk percentage is voor klinische colleges.

\section{Evolutie van de voorbereidingstijd}

De resultaten betreffende de voorbereidingstijd zijn weergegeven in figuur 2 . Het gemiddelde aantal uren dat studenten aangeven, bedraagt $<1.5$ uur voor $29 \%$ van de studenten, tussen 1.5 -2 uur voor $33 \%$ en $>2$ uur voor $38 \%$. Er wordt meer tijd besteed aan individueel opzoekwerk dan aan voorbereiding in de groep. De opgegeven voorbereidingstijd voor groeps- werk bedraagt gemiddeld 61.8 minuten ( $\mathrm{SD}=24.6$ minuten $)$ voor de studenten uit reeks 1 en 52.8 minuten $(\mathrm{SD}=28.8 \mathrm{minu}$ ten) voor de studenten uit reeks 2 . Het verschil tussen de studenten uit beide reeksen is significant (ANOVA; $\mathrm{p}<.001$ ). In beide reeksen treedt in de loop van de acht weken een significante daling op in de werktijd in de groep (ANOVA; $\mathrm{p}<.001$ ) en deze werktijd varieert significant per weekdag (ANOVA; $\mathrm{p}<.001$ ). Voor de colleges van de disciplines uit groep 5 is de groepsvoorbereidingstijd significant lager dan voor de colleges van de andere disciplines (t-toetsen; p's < .001). Aan voorbereiding voor de colleges heelkunde wordt significant meer tijd besteed dan aan voorbereiding voor de colleges gynaecologie en pediatrie (respectievelijk p < .01 en $\mathrm{p}<.05$ ). Er zijn geen significante verschillen wat betreft tijd besteed aan groepswerk tussen les 1 en 2 .

De studenten geven aan gemiddeld 74.4 minuten ( $\mathrm{SD}=32.4 \mathrm{~min}$.) te besteden aan individueel opzoekwerk tijdens reeks 1 en 69 minuten (SD = 36 min.) tijdens reeks 2 . Deze verschillen zijn significant (ANOVA; $\mathrm{p}<.001$ ). In beide reeksen daalt de indivi-

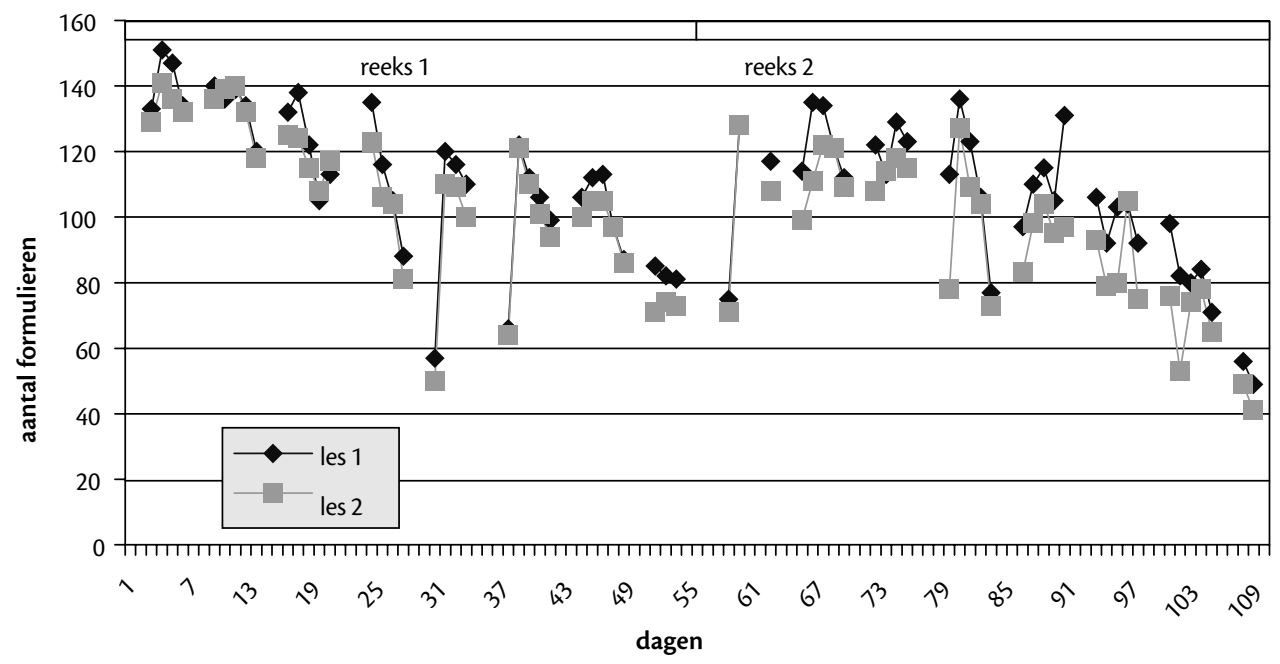

Figuur 1. Gemiddeld aantal formulieren per les per reeks. 


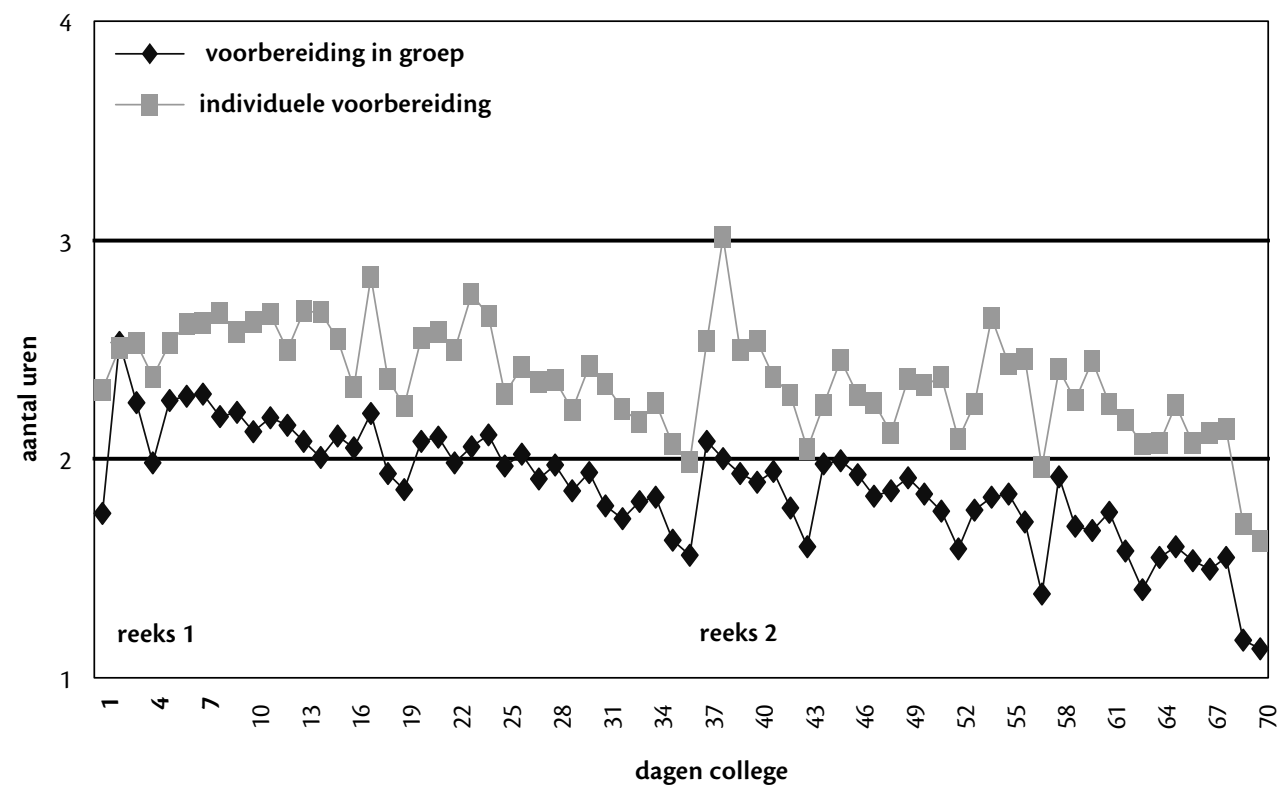

Figuur 2. Verloop van de voorbreidingstijd per reeks.

duele opzoektijd significant in de loop van de acht weken (ANOVA; $\mathrm{p}<.001$ ). De individuele werktijd varieert significant per weekdag (ANOVA; $\mathrm{p}<.001$ ). Voor de colleges gynaecologie, heelkunde en groep 5 zoeken de studenten significant minder informatie op dan voor de colleges inwendige geneeskunde en pediatrie (t-toetsen; p's <.05). Er is geen significant verschil tussen les 1 en 2 in tijd besteed aan opzoekwerk.

De verdeling van het werk in de groep is significant beter in de eerste dan in de tweede reeks (gemiddelde score respectievelijk 4.63 en 4.35; ANOVA; $\mathrm{p}<.001)$. De beoordeling door de studenten van het groepsfunctioneren varieert in beide reeksen significant in de loop van de acht weken (ANOVA; $\mathrm{p}<.001$ ). De taakverdeling is significant zwakker in de eerste week van elke reeks dan in de volgende zes weken (t-toetsen; p's <.001); in de andere significante verschillen is geen duidelijke trend te bespeuren. De groepswerking varieert significant in de loop van de week (ANOVA; $\mathrm{p}<.001$ ). Ze is significant zwakker bij de voorbereiding voor groep 5 dan bij de voorbereiding voor inwendige geneeskunde, heelkunde en pediatrie (t-toetsen; p's < .01) en zwakker bij gynaecologie dan bij heelkunde en pediatrie (t-toetsen; p's < .01). Verder is de werkverdeling in de groep significant zwakker voor inwendige geneeskunde dan voor heelkunde ( $\mathrm{t}$-toets; $\mathrm{p}<.05$ ). Of het gaat om de voorbereiding van de eerste of de tweede les maakt in dit verband geen significant verschil.

\section{Evolutie van de appreciatie}

De appreciatie wordt weergegeven in tabel 1. Deze is over het algemeen gunstig met gemiddelde scores tussen 4 en 5 .

De globale beoordeling (item 20) van de eerste reeks (4.56) is significant beter dan die van de tweede (4.36; ANOVA; $\mathrm{p}<.001)$. In beide reeksen varieert dit globale oordeel significant in de loop van de acht weken (ANOVA; p <.001). Er is een bijna consistente verslechtering in het 
oordeel van week 1-6, terwijl in week 7-8 een hogere score wordt gegeven dan in week 5-6 (t-toetsen; p's < .05). Het globale oordeel varieert significant in de loop van de week (ANOVA; $\mathrm{p}<.001$ ). De colleges van de disciplines inwendige geneeskunde en pediatrie worden significant gunstiger beoordeeld dan de colleges van de andere disciplines (t-toetsen; p's < .001). De appreciatie van de eerste en tweede les verschilt niet significant.

De drie vragen over het voor te bereiden probleem (items 4-6) krijgen gemiddeld scores tussen 4.5 en 5. De gemiddelde score in reeks 1 en 2 voor de relevantie van de casus bedraagt respectievelijk 4.95 en 4.86, voor de uitdaging die de opdracht biedt respectievelijk 4.75 en 4.55 en voor de raadpleging van informatiebronnen respectievelijk 5.05 en 4.82. De score in reeks 1 is steeds significant hoger dan de score in reeks 2 (ANOVA's; p's < .001). Verder varieert de score significant per weekdag (ANOVA's; p's < .001) en weeknummer (ANOVA's; p's < .001).

De zeven vragen over de werkwijze van de docent (items 7-13) krijgen gemiddeld scores tussen 4 en 5 . Dit betekent dat de studenten in reeks 1 en 2 vinden dat de docenten uitgaan van de antwoorden van de door hen aangeduide groep (respectievelijk 4.91 en 4.73), de andere groepen worden betrokken in het denkproces (respectievelijk 4.71 en 4.46), de docenten rekening houden met de inbreng van de studenten (respectievelijk 4.85 en 4.68), ze de studenten weten te boeien (respectievelijk 4.55 en 4.28), ze de studenten aanzetten tot samen actief nadenken over het probleem (respectievelijk 4.66 en 4.44), ze hun redeneringen op een overzichtelijke wijze presenteren (respectievelijk 4.39 en 4.14) en dat de docenten nagaan of de studenten de zich ontwikkelende redenering kunnen volgen (respectievelijk 4.47 en 4.27). De score in reeks 1 is steeds significant hoger dan in reeks 2 (ANOVA's; p's < .001). Verder varieert de score significant per weekdag (ANOVA's; p's < .001) en weeknummer (ANOVA's; p's < .001). Betreffende de werkwijze van de docenten is er een significant verschil tussen les 1 en 2 in de score over het aanzetten tot overzichtelijk presenteren van de redenering (ANOVA; $\mathrm{p}<.05$ ). Dit verschil is toe te schrijven aan een hogere score voor de docenten gynaecologie/verloskunde (t-toets; $\mathrm{p}<.001)$.

De vijf items (14-19) betreffende het verloop van het klinisch college krijgen gemiddelde scores tussen 4 en 5 (na omkering van item 16). Volgens de studenten in reeks 1 en 2 staat het klinisch redeneren centraal (respectievelijk 4.76 en 4.54), wordt het niveau van de basisarts aangehouden (respectievelijk 4.46 en 4.26), is beter gebruik van de didactische middelen niet nodig (respectievelijk 2.35 en 2.37), hebben ze veel geleerd uit de discussies met en door medestudenten (respectievelijk 4.26 en 3.99), voelen ze zich betrokken bij de gezamenlijke uitwerking van het probleem (respectievelijk 4.38 en 4.11) en groeit hun zelfvertrouwen het klinisch werk aan te kunnen (respectievelijk 4.31 en 4.17). Voor elk van deze vragen geldt dat de score in reeks 1 significant hoger is dan in reeks 2 (ANOVA's; p's < .001). Verder varieert de score significant per weekdag (ANOVA's; p's < .001) en weeknummer (ANOVA's; p's < .001). In de eerste week van elke reeks was de behoefte onder de studenten aan beter gebruik van bord en transparanten significant groter dan daarna (t-toetsen; p's < .001).

\section{Factoren}

Uit de resultaten van de factoranalyse werd een oplossing met twee factoren verkozen. Deze verklaart $50 \%$ van de totale variantie. Alle items laden hoog (tussen .63 en .88) op de eerste factor, behalve de 
Tabel 1. Items uit de studentenenquête na elk college met totaal gemiddelde, standaarddeviatie, gemiddelde per reeks en P-waarde betreffende het verschil tussen de gemiddelden per reeks.

\begin{tabular}{lcccccc}
\hline Item & Totaal & & Gem & Gem & \\
& Gem & SD & R1 & R2 & P \\
\hline
\end{tabular}

\section{Voorbereiding}

1. De tijd die ik besteed heb aan voorbereidend groepswerk, $\begin{array}{llllll}1.92 & 0.91 & 2.07 & 1.76 & <0.001\end{array}$ schat ik op ...

2. De tijd die ik besteed heb aan individueel opzoekwerk, schat ik op ...

3. In onze groep heeft iedereen zijn/haar taak of deel van het opzoekwerk op zich genomen.

\section{Probleem}

4. De casus was relevant voor het onderwerp dat in dit college behandeld werd.

5. De opdrachten waren uitdagend.

6. Het probleem verplichtte ons cursussen, handboeken of andere literatuur te raadplegen.

$\begin{array}{lllll}2.40 & 1.14 & 2.49 & 2.30 & <0.001 \\ 4.49 & 1.37 & 4.63 & 4.35 & <0.001\end{array}$

De docent ...

7. Vertrok in dit college van de antwoorden van de door hem aangeduide groep.

8. Betrok de groepen die geen verslag hoefden uit te brengen in het denkproces.

9. Hield rekening met de inbreng van de studenten.

10. Wist de studenten te boeien.

$\begin{array}{lllll}4.91 & 0.90 & 4.95 & 4.86 & <0.001 \\ & & & & \\ 4.65 & 0.94 & 4.75 & 4.55 & <0.001 \\ 4.94 & 0.83 & 5.05 & 4.82 & <0.001\end{array}$

11. Deed de studenten actief samen nadenken over het probleem.

12. Zette de studenten ertoe aan hun redeneringen op een overzichtelijke wijze te presenteren.

13. Ging na of de studenten de zich ontwikkelende redenering konden volgen.

$\begin{array}{lllll}4.83 & 0.91 & 4.91 & 4.73 & <0.001 \\ 4.60 & 1.02 & 4.71 & 4.46 & <0.001 \\ & & & & \\ 4.77 & 0.88 & 4.85 & 4.68 & <0.001 \\ 4.42 & 1.23 & 4.55 & 4.28 & <0.001 \\ 4.56 & 1.00 & 4.66 & 4.44 & <0.001 \\ 4.27 & 1.14 & 4.39 & 4.14 & <0.001 \\ & & & & \\ 4.38 & 1.03 & 4.47 & 4.27 & <0.001\end{array}$

Tijdens dit college ...

14. Stond het klinisch redeneren centraal.

15. Werd het niveau basisarts aangehouden.

$\begin{array}{lllll}4.65 & 1.00 & 4.76 & 4.54 & <0.001 \\ 4.37 & 1.26 & 4.46 & 4.26 & <0.001 \\ 2.36 & 1.31 & 2.35 & 2.37 & <0.001 \\ 4.13 & 1.08 & 4.26 & 3.99 & <0.001 \\ & & & & \\ 4.26 & 1.08 & 4.38 & 4.11 & <0.001 \\ & & & & \\ 4.25 & 1.06 & 4.31 & 4.17 & <0.001\end{array}$

16. Had ik nood aan beter gebruik van bord, transparanten, enz.

17. Heb ik veel geleerd uit de discussies met en door medestudenten.

18. Wist ik me betrokken in de gezamenlijke uitwerking van het probleem.

19. Groeide mijn zelfvertrouwen klinisch werk aan te kunnen.

\section{Kortom}

20. Ik vond dit een goed klinisch college.

$\begin{array}{lllll}4.47 & 1.19 & 4.56 \quad 4.36 & <0.001\end{array}$

drie eerste met ladingen tussen .30 en .73 op de tweede factor. De eerste factor, die het eigenlijke klinische college betreft, verklaart $88 \%$ van de gemeenschappelijke variantie, de tweede factor - de voorberei- ding - verklaart $12 \%$. Twee items werden geschrapt: item 16 wegens onvoldoende hoge factorladingen en item 6 wegens ongeveer even hoge ladingen op beide factoren. 


\section{Het oordeel van de docenten}

Er werden 107 vragenlijsten verwerkt: 56 in reeks 1 , ingevuld door 50 docenten, en 51 in reeks 2, ingevuld door 48 docenten.

De appreciatie van de docenten is over het algemeen gunstig met scores tussen 4-5 (tabel 2). Er zijn geen significante verschillen binnen de reeks tussen les 1 en les 2, gegeven door dezelfde docent en ook niet tussen 'dezelfde' lessen, gegeven in de eerste en de tweede reeks ( $t$-toets op scores, of chikwadraat op scores gereduceerd tot positief $(>3.5)$ of negatief $(<3.5)$ ).

\section{Discussie}

De onderzoeksvragen kunnen als volgt bondig beantwoord worden:

1. Indien het aantal ingevulde formulieren een betrouwbare maat is voor de aanwezigheid in de colleges, dan is de aanwezigheid significant groter in reeks 1 dan in reeks 2 en in les 1 dan in les 2 . In de loop van beide reeksen daalt de aanwezigheid significant.

2. Zowel voor het individuele als voor het groepswerk geldt dat hieraan significant meer tijd besteed wordt in reeks 1 dan in reeks 2 en dat de bestede tijd significant daalt in de loop van beide reeksen.

3. Zowel voor de globale beoordeling als voor de appreciatie van het voor te bereiden probleem, de werkwijze van de docent en de inhoud van het college geldt dat de score significant hoger is in reeks 1 dan in reeks 2 en significant varieert in beide reeksen.

4. Op basis van een factoranalyse kunnen twee factoren onderscheiden worden:

Tabel 2. Items uit de docentenenquête na elk college, met gemiddelde en standaarddeviatie.

\begin{tabular}{|c|c|c|}
\hline Item & Gem & SD \\
\hline \multicolumn{3}{|l|}{ Mijn voorbereiding } \\
\hline $\begin{array}{l}\text { 1. Mijn voorbereiding van dit PoKC verschilde van mijn voorbereiding van een } \\
\text { 'traditioneel' klinisch college. }\end{array}$ & 4.14 & 1.24 \\
\hline $\begin{array}{l}\text { 2. Het bleek mogelijk in mijn voorbereiding de drie componenten - bevraging, } \\
\text { uitdieping, afronding - hun plaats te geven. }\end{array}$ & 4.62 & 0.92 \\
\hline \multicolumn{3}{|l|}{ Het feitelijke verloop } \\
\hline 3. Dit probleemoplossend klinisch college verliep zoals gepland. & 4.53 & 1.05 \\
\hline 4. Ik kwam 'onderweg' voor verrassingen te staan. & 2.68 & 1.35 \\
\hline 5. Ik vond het moeilijk dit PoKC in goede banen te leiden. & 2.30 & 1.08 \\
\hline 6. Ik heb de doelstellingen bereikt die ik voor ogen had. & 4.79 & 0.78 \\
\hline 7. Ik slaagde erin studenten in dit college klinisch te laten redeneren. & 4.65 & 0.77 \\
\hline 8. Ik ben tevreden over de wijze waarop dit college verlopen is. & 4.58 & 0.91 \\
\hline 9. Dit probleemoplossend college heeft me ook zelf geboeid. & 4.81 & 0.95 \\
\hline 10. De studenten hebben zich goed voorbereid op dit college. & 4.33 & 1.29 \\
\hline $\begin{array}{l}\text { 11. De studenten toonden belangstelling voor het probleem dat in het college aan } \\
\text { bod is gekomen. }\end{array}$ & 4.86 & 0.83 \\
\hline 12. De medewerking van de studenten liet te wensen over. & 2.27 & 1.14 \\
\hline 13. Een nieuw college over dit probleem zou ik anders aanpakken. & 2.66 & 1.17 \\
\hline \multicolumn{3}{|l|}{ Het vignet } \\
\hline 14. Het vignet bevorderde de probleemanalyse. & 4.81 & 0.73 \\
\hline $\begin{array}{l}\text { 15. Ik ga verandering(en) aanbrengen in de inhoud van het vignet (casus of } \\
\text { bijhorende opdrachten). }\end{array}$ & 2.75 & 1.26 \\
\hline
\end{tabular}


de eerste (15 items) betreft het eigenlijke klinische college en de tweede (items 1-3) de voorbereiding.

5. De appreciatie van de docenten is over het algemeen gunstig: net als bij de studenten liggen de gemiddelde scores tussen 4-5.

6. De verschillen tussen les 1 en les 2, gegeven door dezelfde docent, en tussen 'dezelfde' lessen in reeks 1 en reeks 2 zijn niet significant.

In overeenstemming met de literatuur is het oordeel over de probleemgestuurde onderwijscomponent in het traditionele curriculum zowel van de studenten als van de docenten positief. ${ }^{1-9}$ Aan de hand van de factoranalyse kunnen in de studentenvragenlijst twee deelverzamelingen onderscheiden worden: de items betreffende de voorbereiding en het klinisch college. Dit bevestigt dat het om twee afzonderlijke leermomenten gaat. Door de probleemgestuurde werkwijze verschijnt de voorbereiding als afzonderlijk leermoment. Het aantal items over de voorbereiding is te klein om een onderscheid te kunnen maken tussen zelfstudie en groepswerk als afzonderlijke factoren.

Uit de docentenevaluatie komen geen significante verschillen naar voren in het oordeel van docenten over verschillende colleges. De ervaring van de docenten was echter over het algemeen beperkt tot slechts vier lessen, terwijl de studenten maximaal ongeveer zeventig lessen konden beoordelen, waardoor een meer gedifferentieerde evolutie in kaart gebracht kan worden.

Zowel voor de globale beoordeling als voor de drie onderdelen betreffende de klinische colleges is de score in reeks 1 significant hoger dan de score in reeks 2 . Vergelijkbare verschillen tussen de reeksen worden ook aangetroffen voor aanwezigheid en voorbereidingsduur: er worden significant meer formulieren ingevuld in reeks 1 en de studenten steken meer tijd in zowel de individuele zelfstudie als in het groepswerk in reeks 1 . Dus niet alleen de appreciatie, ook de motivatie en de inzet zijn groter in reeks 1 . Twee elementen bieden vermoedelijk een verklaring voor deze verschillen. De meeste PoKC's van de eerste reeks werden geobserveerd door een lid van de Dienst Onderwijs, terwijl dit zelden het geval was tijdens de tweede reeks. In tegenstelling tot de studenten die de eerste reeks colleges volgden, dienden sommige studenten uit de tweede reeks nog aan extra, interfererende onderwijsverplichtingen te voldoen.

Verder daalt in de loop van elke reeks de geschatte aanwezigheid en de tijd voor zowel de individuele als de groepsvoorbereiding. Dit kan verband houden met een afnemende belangstelling of motivatie en de prioriteit die - naar het einde van de reeks toe - gegeven wordt aan het voorbereiden van het examen boven het voorbereiden en volgen van de lessen. De appreciatie van de studenten varieert significant in elke reeks, zonder evenwel systematisch te dalen. Vermoedelijk wordt deze score veeleer bepaald door de individuele colleges en docenten. Hoewel de geschatte aanwezigheid significant groter is in de eerste les dan in de tweede, verschilt de voorbereidingsduur van de lessen niet en evenmin de appreciatie. Dit laatste kan te wijten zijn aan zelfselectie: de studenten die het meest tevreden zijn over de colleges blijven deze volgen, de anderen zijn meer geneigd af te haken na de eerste les.

Ten slotte zijn er nog verschillen tussen de disciplines. Er worden significant minder formulieren ingevuld na de colleges gynaecologie dan na de colleges heelkunde of pediatrie. Mogelijk speelt hier een rol dat de colleges van gynaecologie op maandag werden gegeven. Er wordt significant minder tijd besteed aan de 
voorbereiding van de colleges van groep 5 dan aan de voorbereiding voor de colleges van inwendige geneeskunde of pediatrie. Een mogelijke verklaring is dat de lessen van groep 5 op vrijdagvoormiddag gegeven werden, terwijl de andere in de namiddag tijdens de week gegeven werden, zodat de studenten zich in de voormiddag konden voorbereiden. De verschillen tussen de disciplines kunnen bovendien mede bepaald zijn door de verschillen in gepercipieerde relevantie voor de toekomstige beroepspraktijk.

\section{Conclusie}

Aan het einde van een traditionele opleiding zijn zowel de studenten als de docenten over het algemeen tevreden over de PoKC's. Dit onderzoek toont een variatie aan in aanwezigheid, voorbereidend werk en appreciatie bij een probleemgestuurde onderwijscomponent van enige duur, die gemist wordt bij een eenmalige evaluatie. Vermoed wordt dat deze variatie te wijten is aan talrijke factoren. De bevindingen resulteerden in een bijsturing van de formule via onder meer een introductiedag voor studenten en geen vaste weekdag meer per discipline.

\section{Literatuur}

1. Vernon DTA, Campbell JD, Dally JC. Problembased learning in two behavioral sciences courses at the University of Missouri - Columbia. Acad Med 1992; 67:349-50.

2. Vasconez HC, Donnelly MB, Mayo P, Schartz RW. Student perceptions of the effectiveness of a problem-based surgery curriculum. Acad Med 1993;68 (10 Suppl):S28-S30.

3. Morrison JM, Murray TS. An experiment in problem-based learning. Med Educ 1994;28:139-45.
4. Schwartz RW, Donnelly MB, Sloan DA, Strodel WE. Residents' evaluation of a problem-based learning curriculum in a general surgery residency program. Am J Surg 1997;173:338-41.

5. Antepohl W, Herzig S. Problem-based learning versus lecture-based learning in a course of basic pharmacology: a controlled, randomized study. Med Educ 1999;33:106-13.

6. Martenson D, Eriksson H, Ingelman-Sundberg M. Medical chemistry: evaluation of active and problem-oriented teaching methods. Med Educ 1985; 19:34-42.

7. West DA, West MM. Problem-based learning of psychopathology in a traditional curriculum using multiple conceptual models. Med Educ 1987;21:151-6.

8. Sokas RK, Diserens D, Johnston MA. Integrating occupational health into the medicine clerkship using problem-based learning. J Gen Intern Med 1991;6:450-4.

9. Bernstein P, Tipping J, Bercovitz K, Skinner HA. Shifting students and faculty tot a PBL curriculum: attitudes changed and lessons learned. Acad Med 1995;70:245-7.

De auteurs:

Drs. J. Beullens is psycholoog en wetenschappelijk medewerker aan de Dienst Onderwijs van de Faculteit Geneeskunde, KU Leuven.

Prof. dr. E. Struyf is onderwijskundige en leidt de Dienst Onderwijs van de Faculteit Geneeskunde, KU Leuven.

Prof. dr. H. Jaspaert, pedagoog, is emeritus hoofddocent en leidde de Dienst Onderwijs van de Faculteit Geneeskunde, KU Leuven.

Prof. dr. B. van Damme is vice-decaan van de Faculteit Geneeskunde van de KU Leuven en hoofd van de dienst Pathologische Ontleedkunde.

Drs. C. Aubry is verpleegkundige en coördinator van het Vaardigheidscentrum van de Faculteit Geneeskunde, $K U$ Leuven.

Prof. dr. P.J. Janssen is emeritus gewoon hoogleraar Schoolpsychologie in de Faculteit Psychologie en Pedagogische Wetenschappen van de KU Leuven en als extern consulent betrokken bij dit onderzoek.

Correspondentieadres:

Drs. Johan Beullens, Dienst Onderwijs Faculteit Geneeskunde, KU Leuven, Minderbroedersstraat 17, B-3000 Leuven, België, Johan.Beullens@med.kuleuven.ac.be.

\section{Summary}

Introduction: In the academic year 2000-2001 problem-solving clinical seminars were introduced in the traditional undergraduate medical curriculum of the Catholic University of Leuven, Belgium. Two eight-week series of some 70 seminars were offered. Before the seminars groups of five students worked on one or more vignettes consisting of a patient case and questions. Students collected information individually. At the seminar the solutions were presented and discussed, guided by a medical teacher. The seminars were evaluated by a questionnaire survey in the academic year 2000-2001. 
Evolutie waardering probleemoplossingsgerichte klinische colleges $\mid$ J. Beullens et al.

Method: Student questionnaires (20 items) and teacher questionnaires (15 items) could be completed after each seminar. Most items were statements to be judged on a six-point scale.

Results: 14,448 student questionnaires were processed. In the first series more questionnaires were completed than in the second series and the same applied for the first seminar compared with the second seminar. Attendance appeared to decrease in each series and it varied between disciplines. Preparation time showed a very similar pattern. Students' appreciation was generally favourable. 107 teacher questionnaires were processed. Appreciation was generally favourable. There were no differences between the seminars.

Discussion and conclusion: In general both students and teachers were satisfied with the seminars. The longitudinal evaluation format showed a variation in attendance, preparation time and appreciation in a problem based education component that would have been missed with a one-time evaluation. The findings have resulted in adaptations of the format, such as an introduction day for students and the abandonment of the principle of a fixed day of the week for each discipline. (Beullens J, Struyf E, Jaspaert H, Van Damme B, Aubry C, Janssen PJ. The evolution of student and teacher appreciation of problem-solving clinical seminars. Dutch Journal of Medical Education 2004;23(2):80-90.) 